$118 \mid \mathrm{P}$ a g e

Michael Collins (2012) 'Rabindranath Tagore and the Politics of Friendship', South Asia: Journal of South Asian Studies, 35:1, pp. 118-142

DOI: $10.1080 / 00856401.2011 .648908$

Online: http://dx.doi.org/10.1080/00856401.2011.648908

\title{
Rabindranath Tagore and the Politics of Friendship
}

\author{
Michael Collins
}

UCL

\begin{abstract}
Caught between an arrogant European modernist elite and a proprietorial Indian nationalism, Tagore challenged the spatial dimensions of modernity by critiquing both Eurocentrism and a simplistic anti-imperialism. Tagore did build bridges with some Western intellectuals and social activists but much of his life illustrates the difficulties of meaningful cross-cultural relations and the shortcomings of a liberal 'politics of friendship'. If this is in part due to the inadequacy of translation, then we need more and better translations. Rather than resurrecting a platitudinous 'cosmopolitan' World Citizen, Tagore's work should require us to think more critically about parallel modernities and different ways of imagining our futures. As China and India, perhaps above all others, grow in economic, political and cultural strength, these questions are likely to become more pressing.
\end{abstract}

Keywords: Tagore, Yeats, Andrews, Thompson, politics of friendship, liberalism, anti-colonialism, nationalism, modernity

\begin{abstract}
$* * *$
You have got into some conventional habits... such as calling me Gurudeb and making pranam to me. Drop them. For I know there are occasions when they hurt you and for that very reason you are truly discourteous to me. You know I never cared to assume the role of a prophet or teacher; I do not claim homage from my fellow beings. ${ }^{1}$
\end{abstract}

\footnotetext{
${ }^{1}$ Krishna Dutta and Andrew Robinson, Rabindranath Tagore: The Myriad-Minded Man (London: Bloomsbury, 1997), p.230.
} 
Despite the sycophants that often surrounded him, Rabindranath Tagore craved for an engaged critique, especially in the West. Yet, as I argue in what follows, he did not always take such critique particularly well. However, at a trans-imperial and cross-cultural level Tagore believed that building friendships and communicating ideas from East to West was a method-if not a modelfor achieving political change and progress. His letter to his young friend Willie Pearson-quoted above-cannot be taken at face value for, although Tagore sometimes became impatient with his many followers, he also envisaged for himself a central role in a historically determined process of East-West reconciliation and mutual learning. In a January 1913 letter to C.F. Andrews, Tagore wrote that

[t] he problem of race conflict is the greatest of all that men have been called upon to solve. . .different races and nations of the Earth have come nearer each other than ever they did before. But we have not been ready to accept the responsibilities of this wider humanity. Men are still under the thraldom of the spirit of antagonism which has been associated with a narrow sentiment of nationality... I feel that the time has come, and after all kinds of patch-work of superficial experiments the spiritual nature of man is getting ready to take up the task and broaden the path of reconciliation of all different races and creeds. $^{2}$

Writing later that year, Tagore seemed to accept his new vocation: 'the world is waiting for its poets and prophets [and] when the call of humanity is poignantly insistent then the higher nature of man cannot but respond ${ }^{3}{ }^{3}$

Tagore did, therefore, assume the role of prophet and teacher, and he aimed to communicate to a wide audience in the West. Firstly, after 1912 he began to write essays, poetry and other prose directly in English. Translations of Bengali work also followed, mostly published by Macmillan. Secondly, he courted the friendship and engagement of elite intellectuals with whom he might develop and share ideas and common experiences, and who might further his project of East-West cultural and intellectual dialogue. W.B. Yeats was a celebrated metropolitan example. Thirdly, Tagore relied-with mixed success-upon

\footnotetext{
${ }^{2}$ Rabindranath Tagore to C.F. Andrews, Jan. 1913, C.F. Andrews' notebook, C.F. Andrews Papers, Rabindra Bhavana. The original letter has been lost, but a draft was copied by Andrews into his notebook. ${ }^{3}$ Rabindranath Tagore, 'Race Conflict', (1913) in Sisir Kumar Das (ed.), The English Writings of Rabindranath Tagore: Volume II (New Delhi: Sahitya Akademi, 1996), p.363.
} 
'go-betweens' such as C.F. Andrews and E.J. Thompson. These two men cannot really be taken seriously as intellectuals on a par with Yeats, but they earnestly engaged with India and with Tagore, and they aimed, in rather different ways, to communicate Tagore to Western audiences and thereby effect an improvement in the relationship between Britain and India, coloniser and colonised.

In this article I wish to make a few points about this practice of building friendships across cultural and national boundaries. In this sense, as well as being an article about the history of Tagore's encounters with Western intellectual and cultural figures, it is also connected, albeit at a tangent, to recent work on cosmopolitanism. ${ }^{4}$

Cosmopolitanism and Friendship

The kind of social encounter that Tagore sought stood in contradistinction both to cosmopolitanism, which was seen as something rather abstract; and nationalism, a political ideology that ran counter to Tagore's interpretation of Advaita Vedanta and indeed to his interpretation of World History. ${ }^{5}$ That Tagore was not a nationalist in any meaningful sense of the word is reasonably clear. ${ }^{6}$ But nor was he a cosmopolitan. As he wrote in 1917, 'neither the colourless vagueness of cosmopolitanism, nor the fierce self idolatry of nationworship is the goal of human history'. ${ }^{7}$ According to an anonymous entry in The Modern Review of June 1917, certain reviewers of Tagore's 1916 lectures were labouring 'under the misapprehension' that in his speech 'The Cult of Nationalism', ${ }^{8}$ Rabindranath 'has actually proposed to do away with nations altogether' to form a 'universal brotherhood of man'. In other words, the accusation made in America was that Rabindranath 'ha[d] preached the petted and pious platitudes of whining sanctimonious preachers that all men should sink their differences. . and love one another without quarrelling or fighting

\footnotetext{
${ }^{4}$ See for example Martha C. Nussbaum, For Love of Country: Debating the Limits of Patriotism (Boston: Beacon Press, 1996); Timothy Brennan, At Home in the World: Cosmopolitanism Now (Cambridge, MA: Harvard University Press, 1997); Pheang Cheah and Bruce Robbins (eds), Cosmopolitics: Thinking and Feeling Beyond the Nation (Minneapolis: University of Minnesota Press, 1998); Kwame Anthony Appiah, Cosmopolitanism: Ethics in a World of Strangers (London: Penguin, 2007); and Rahul Rao, Third World Protest: Between the Home and the World (Oxford: Oxford University Press, 2010).

${ }^{5} \mathrm{I}$ explore and (hopefully) justify this claim at some length in my book Empire, Nationalism and the Postcolonial World: Rabindranath Tagore's Writings on History, Politics and Society (London: Routledge, 2011).

${ }^{6}$ See ibid., esp. Ch.3.

${ }^{7}$ Rabindranath Tagore, Nationalism (London: Macmillan, 1917), p.5, emphasis added.

${ }^{8} \mathrm{~A}$ lecture-the content of which formed the main output of his American tour in 1916-given in Pasadena on 10 October 1916.
} 
ever, and so on and so on'. ${ }^{9}$ But 'such a colourless cosmopolitanism is entirely out of his programme'. ${ }^{10}$ Tagore argued that ' $[\mathrm{t}] \mathrm{h}$ e world would be unbeautiful and monotonous without variety', and saw cosmopolitanism as a threat to this. ${ }^{11}$ Instead, ' $[\mathrm{w}] \mathrm{e}$ shall realise that only through the development of racial individuality can we truly attain to universality, and only in the light of the spirit of universality can be we perfect individuality'. ${ }^{12}$ As Sarvepalli Radhakrishnan has added, in this respect 'a vague cosmopolitanism is no good'. ${ }^{13}$

Clearly the term cosmopolitanism has multiple meanings that cannot be explored fully here, with applications in political theory, law, sociology, economics and international relations. ${ }^{14}$ What we can say is that in Tagore's understanding the cosmopolitan world was one of monotonous similitude, a kind of lowest common denominator at the level of elite culture in which deep-rooted cultural differences, and indeed history itself, were glossed over. Tagore had denounced Theosophy for its similar effect in the sphere of religion. Tagore's vision was in some ways rather old fashioned. He saw himself as a representative of the East, or of India at least. He did not seek any kind of synthesis of East and West, but a high-level dialogue. His universalism was grounded in Idealism. At the level of the Real, he was particularly concerned with the preservation of cultural difference. In this sense he articulated and practised a version of culturalism, as explored in stimulating detail in Andrew Sartori's recent book. ${ }^{15}$

Those who label Tagore 'cosmopolitan' do so without paying due attention to how Tagore actually thought about it himself. It seems to me that-from a Tagorean perspective-whereas the universalism inherent in the cosmopolitan ideal is either abstract or reductive, the interactions of elite trans-national and trans-imperial social groups-based around friendships-were more concrete. Friendship better describes what Tagore sought in his encounters with Western intellectuals and cultural figures, and it provides a better approach to understanding the social and intellectual history of such phenomena. For this reason, the various accretions of meaning that inhere in the term 'cosmopolitanism', which ultimately amount to a moral ideal in which

\footnotetext{
${ }^{9}$ Literatus, 'Rabindranath Tagore in America', in The Modern Review, Vol.21, no.6 (1917), p.661.

${ }^{10}$ Ibid.

${ }^{11}$ Rabindranath Tagore, Kewanee Courier (Illinois) (30 Oct. 1916), published in ibid, p.661.

${ }^{12}$ Rabindranath Tagore, 'My Interpretation of India's History', quoted in Sarvepalli Radhakrishnan, The

Philosophy of Rabindranath Tagore (London: Macmillan, 1918), p.284.

${ }^{13}$ Ibid.

${ }^{14} \mathrm{~A}$ useful overview can be found in Andrew Vincent, Nationalism and Particularity (Cambridge: Cambridge University Press, 2002), Ch.8.

${ }^{15}$ Andrew Sartori, Bengal in Global Concept History: Culturalism in the Age of Capital (Chicago: University of Chicago Press, 2008).
} 
humanity constitutes a single community, are better replaced by the phrase 'the politics of friendship'. ${ }^{16}$ What I am ultimately interested in is the function these friendships were supposed to perform in actualising political, social or philosophical ideas, and ultimately, change. I am suggesting that Tagore shared in an interwar belief in the historical role of the civilised individual as a representative of cultures, a leader of cultural change at a societal level and a mediator of understanding at a cross-cultural level. This faith in the role of elites can be seen as a form of liberalism distinct from the mass politics of socialism and Fascism, despite the fact that it intersected with a very wide range of political opinion and practice.

The fundamental conservatism of this approach is elucidated by Raymond Williams in his 1980 essay on the 'Bloomsbury Fraction', which addresses Bloomsbury's ostensibly enlightened and cosmopolitan attitudes. He argues that despite its supposed avant garde and progressive status, Bloomsbury was 'carrying [forward] the classical values of bourgeois enlightenment'.

It was against cant, superstition, hypocrisy, pretension and public show. It was also against ignorance, poverty, sexual and racial discrimination, militarism and imperialism. But it was against all these things in a specific moment of liberal thought. What it appealed to, against all these evils, was not any alternative idea of a whole society. Instead it appealed to the supreme value of the civilized individual, whose pluralisation, as more and more civilized individuals, was itself the only acceptable social direction. ${ }^{17}$

The key idea of the 'pluralisation of civilised individuals' grasps much of what is essential to Tagore and his network of Western friends and interlocutors. As Andrews wrote to Tagore in 1914, ' $[$ t] he greatest good I have been able to do to bring peace and love, instead of strife and hate, has been through my friendship with you and through the place that you now hold in the heart of East and West alike'. ${ }^{18}$ Tagore very much shared this belief. The trans-national,

\footnotetext{
${ }^{16}$ From Derrida's deconstructionist perspective all 'natural' identity categories-family, clan, nation and class, as well as the associated concepts of community, culture, nation etc--are ultimately dependent on language and are therefore discursive conventions. In Derrida's usage the politics of friendship is a utopian vision transcending these discursively policed identities. See Jacques Derrida, The Politics of Friendship (London: Verso, 2005). My own usage of the term is in the context of social and intellectual history rather than normative theory.

${ }^{17}$ Raymond Williams, Culture and Materialism (London: Verso, 1980), pp.148-69.

18 Andrews to Tagore, 14 Jan. 1914, Andrews Files, Tagore Papers, Rabindra Bhavana.
} 
trans-imperial friendships he established were intended to be pathways to a more enlightened future.

In an Indian context, Tagore was not a liberal in his political and social thinking. Far from it. His anti-politics and his valorisation of an Indian socialreligious model of civilisation over the Western, political and state-centred model are clear throughout his writings. For Tagore, individual freedom is only realisable within the harmony of the whole, whether that be society or a more cosmic, spiritual whole. But outside of India, at the level of cross-cultural dialogue-with all its attendant implications for the colonial relationship between West and East, and specifically Britain and India-he was, in an important sense, a liberal. By this I mean that he sought to effect a change in the relationship between coloniser and colonised on the basis of liberal methods; a liberal politics of friendship that saw the pluralisation of the highminded, civilised individual as the only acceptable method of political change. However, despite the high-minded intentions-or pretensions-of the protagonists, the politics of friendship often collapsed under the pressure of misunderstanding and confusion, not to mention the wilful invocation of cultural, national, religious and social hierarchy.

W.B. Yeats: The Condescension of Proximity

From a distance, Tagore was a fine object of fantasy and desire. His reception and interpretation in London in 1912 and 1913 exemplified many of the commonplace tropes of the spiritually-minded, 'other-worldly' Oriental. The Easterner in the metropole was lauded as a representative of a more 'harmonious' and 'unified' civilisation, one which had supposedly existed in Europe and which some Europeans still hoped to recover. W.B. Yeats had been deeply moved by Tagore's poems in Gitanjali, and following meetings in London during the summer of 1912, Ezra Pound had written to a friend that in Tagore's company he felt like 'a painted Pict with a stone war-club'. ${ }^{19}$ In March 1913, Pound published an adulatory essay in the Fortnightly Review in which he compared Tagore's work to 'the poetic piety of Dante'. ${ }^{20}$

As perhaps the most famous of Tagore's Western interlocutors, W.B. Yeats often features in biographical commentaries on 'Tagore and the West', most

\footnotetext{
${ }_{19}$ Ezra Pound to Dorothy Shakespear, 4 Oct. 1912, published in A. Walton Litz and Omar S. Pound, Ezra Pound and Dorothy Shakespear: Their Letters, 1910-1914 (London: Faber, 1985), p.163, quoted in Krishna Dutta and Andrew Robinson, Rabindranath Tagore: An Anthology (London: Picador, 1997), p.102.

${ }^{20}$ Ezra Pound, 'Rabindranath Tagore', in Fortnightly Review, Vol.99 (Mar. 1913).
} 
specifically regarding Tagore's visit to Britain in 1912 and Yeats' role as 'midwife' to Tagore's Western reputation. As I have argued elsewhere, Yeats' role in securing the Nobel Prize in Literature for Rabindranath has been exaggerated. ${ }^{21}$ Even so, it is almost universally assumed that Tagore recognised in Yeats a common poetic genius, and that Yeats, in turn, recognised Tagore as a 'great poet'. ${ }^{22}$ This is a somewhat problematic perspective in a number of ways. Ganesh N. Devy suggests that when Yeats first met Tagore, he 'was already a famous poet, a known leader of the Irish literary movement' ${ }^{23}$ But Yeats was yet to fully establish himself as the preeminent poet of his time, a status that would not come until at least the publication of The Wild Swans at Coole (1917), and perhaps not even until The Tower (1928). ${ }^{24}$ This makes Yeats' recognition of Tagore in 1912 not quite as significant as some critics would have it, where Yeats sometimes appears to speak for the entire Western literary establishment. ${ }^{25}$ It is also worth bearing in mind that in 1912, although Tagore was aware of who Yeats was, he was unacquainted with his work.

More significant, however, is the absence of a contextualised account of Yeats' interest in India as it stood in 1912, how he came to 'know' the East and precisely what, in Yeats' eyes, Tagore represented. In fact, Yeats' comprehension of 'the East' was not only limited, it was also wrought by his encounters with Theosophy, which can hardly be seen as an objective or comprehensive 'introduction to the Orient'. Yeats' knowledge of Tagore was embarrassingly vague. He confesses in his introduction to the 1913 edition of Gitanjali that 'though these prose translations from Rabindra Nath Tagore have stirred my blood as nothing has for years, I shall not know anything of his life, and of the movements of thought that have made them possible, if some Indian traveller

\footnotetext{
${ }^{21}$ My research on Swedish papers in the Nobel Committee archive uncovered the fact that a member of the Nobel Committee could read Bengali, and that this enabled them to access a wider range of Tagore's work, well beyond Gitanjali, the translation and promotion of which Yeats had claimed credit for. See Michael Collins, 'History and the Postcolonial: Rabindranath Tagore's Reception in London, 1912-1913', in The International Journal of the Humanities, Vol.4, no.9 (Aug. 2007), pp.71-84; and Collins, Empire, Nationalism and the Postcolonial World, Ch.2.

${ }^{22}$ Louise Blakeney Williams, 'Overcoming the Contagion of Mimicry: The Cosmopolitan Nationalism and Modernist History of Rabindranath Tagore and W.B. Yeats', in The American Historical Review, Vol.112, no.1 (2007), p.69.

${ }^{23}$ Ganesh N. Devy, 'The Indian Yeats', in Toshi Furomoto et al (eds), International Aspects of Irish Literature (Gerrards Cross: Colin Smythe, 1996), p.99.

${ }^{24}$ A 1913 'referendum' on the 'three greatest living English poets in order of excellence', conducted by the Journal of Education, placed Yeats tenth, with Rudyard Kipling in first place. See press cutting in E.J. Thompson Papers, MS Eng. c. 5279, Folio 56, Bodleian Library, Oxford.

${ }^{25}$ For example see Hirendranath Datta, 'Tagore and Yeats', in Visva-Bharati Quarterly, Vol.17, no.1 (May-July 1951), pp.29-34.
} 
will not tell me'. ${ }^{26}$ The traveller with whom Yeats engages in dialogue about Tagore is a 'distinguished Bengali doctor', ${ }^{27}$ whose identity remains unknown, as does the level of his expertise in Bengali literary culture. As Mary Lago has commented, 'most persons, including Yeats, had little accurate information about the sources of his [Tagore's] philosophy [or] of the social and cultural forces that had influenced him and his work'. ${ }^{28}$

Rather than genuine dialogue and mutual learning, the politics of friendship in the case of Yeats meant the instrumentalisation of Tagore-and the East more generally-as part of a project of European cultural recovery. Tagore functioned not as an independent thinker or agent of historical change in his own right, but as something of an aesthetic object. 'Damn Tagore', Yeats wrote to William Rothenstein in 1935. 'We got out three good books, [Thomas] Sturge Moore and I, and then, because he thought it more important to see and know English than to be a great poet, he brought out sentimental rubbish and wrecked his reputation. Tagore does not know English, no Indian knows English'. ${ }^{29}$

In fact, the early green shoots of cross-cultural growth did not last even into the summer of 1913. Faced with a mountain of half- (and often badly-) translated work, Pound wrote to the American publisher Harriet Monroe that Tagore's poetry amounted to just 'more theosophy', 30 adding that 'Tagore's philosophy hasn't much in it for a man who has "felt the pangs" and been pestered with Western civilisation'. ${ }^{31}$ This scepticism as to whether Tagore's philosophy could really connect with the tragic persona of 'modern man' was something that set in early amongst the Bloomsbury group. By 1916 D.H. Lawrence had dismissed the 'wretched worship of Tagore' as 'sheer fraud'. 'The East is marvellously interesting, for tracing our steps back. But for going forward, it is nothing. All it can hope for is to be fertilised by Europe, so it can start on a new phase'.$^{32}$ Yeats soon distanced himself from Tagore, and whilst his encounters

\footnotetext{
${ }^{26}$ W.B. Yeats, 'Introduction to Gitanjali' (1912), in Sisir Kumar Das (ed.), The English Writings of Rabindranath Tagore: Volume I (New Delhi: Sahitya Akademi, 1994), p.38.

${ }^{27}$ Ibid.

${ }^{28}$ Mary Lago, 'The Parting of the Ways: A Comparative Study of Yeats and Tagore', in Indian Literature, Vol.6, no.2 (1963), p.5.

${ }^{29}$ Allan Wade (ed.), The Letters of W.B. Yeats (London: Rupert Hart-Davis, 1954), pp.834-5.

${ }^{30}$ Ezra Pound to Harriet Monroe, 22 April 1913, in D.D. Paige, The Selected Letters of Ezra Pound, 19071941 (London: Faber, 1982), p.19. Strangely, this is frequently misquoted as 'mere theosophy': the subtle change in emphasis is important. Pound claims that the translation work was only at Tagore's instigation: 'God knows I didn't ask for the job of correcting Tagore'. See Paige, The Selected Letters of Ezra Pound, p.19. ${ }^{31}$ Ibid.

32 D.H. Lawrence to Lady Otteline Morrell, 24 May 1916, in James T. Boulton and George J. Zytaruk, The Letters of D.H. Lawrence: Volume II, 1913-1916 (Cambridge: Cambridge University Press, 2002), p.608,
} 
with Indian philosophy and religious thought outlasted the Tagore moment, he found it difficult to move beyond the problematic posed by Pound: 'Why should India', Yeats said, during conversations with a young Bengali scholar in the 1930s, 'be always thinking of peace-shanti? Life is a conflict'. ${ }^{33}$

Despite popular perceptions then, Yeats' engagement with Tagore was embarrassingly superficial. But if this initial contact with figures such as Yeats and Pound led to the emergence of points of criticism and ultimate rejection, theirs were not the only efforts at cross-cultural communication. C.F. Andrews and Edward Thompson pursued a politics of friendship in India that others within metropolitan cultural and literary circles sometimes professed, but were rarely able to extend across the cultural boundaries of East and West. Andrews and Thompson lived in India, learned Bengali and spent long periods of time in Tagore's cultural world. More significantly, they held a desire to effect a Christian-inspired political reconciliation between East and West, India and Britain. ${ }^{34}$ Motivated by the Christian idea of atonement-a concept that featured in the writing of both men-their concerns went well beyond the level of the aesthetic. Like Tagore, they sought a change in the moral basis of the colonial relationship. But was this kind of approach capable of augmenting a different kind of encounter?

C.F. Andrews: Atonement as Self-Transformation

Andrews was ordained as an Anglican priest in 1897 and became the principal of St. Stephen's College in Delhi in 1904. Following his time in South Africa with Gandhi, he became one of the first Englishmen to build a strong relationship with Tagore, whom he met in London in the summer of 1912. Andrews was in Birmingham visiting his ailing mother, with whom he had an intense emotional bond, but he travelled to London in an effort to meet the poet of whom he had heard so much. His chance came on 7 July, when he was invited to Tagore's Gitanjali reading at William Rothenstein's Hampstead residence. ${ }^{35}$ After meeting Tagore, Andrews published an article entitled 'An Evening with Rabindra' in The Modern Review of August 1912 in which he

emphasis in original. Also quoted in Dutta and Robinson, Rabindranath Tagore: The Myriad-Minded Man, p.199.

${ }^{33}$ R.K. Dasgupta, Rabindranath Tagore and William Butler Yeats (Delhi: University of Delhi, 1965), p.22

${ }^{34}$ Benita Parry, Delusions and Discoveries: India in the British Imagination, 1880-1930 (London: Verso, 1998), p.153.

${ }^{35}$ Andrews was invited by H.W. Nevinson, a friend of Rothenstein, whom Andrews met at the Congress of Universities of the British Empire. See Hugh Tinker, The Ordeal of Love: C.F. Andrews and India (Oxford: Oxford University Press, 1998), p.56. 
wrote of 'the glad exultation that my own country was doing homage at last to the genius of India, revealed through her greatest living poet'. ${ }^{36}$ Andrews' sense, in 1912, was that British-Indian relations could be repaired by paying due respect to Indian culture and civilisation. Such a perspective was widespread at the time: honouring Tagore was seen, as Yeats had put it, as a piece of 'wise imperialism' ${ }^{37}$

The quality of his translations was an ever-present concern for Tagore. Andrews was neither a literary critic nor was he particularly familiar with Bengali, but during October 1912, before Tagore's departure for America, Andrews had persuaded Tagore to make changes to the proofs of the forthcoming India Society limited edition of Gitanjali, the first Englishlanguage publication. When Yeats heard news of this, he chided Tagore: 'the amateur', he said, 'is never to be trusted'. ${ }^{38}$ Despite this, in early 1914 Tagore continued to ask Andrews to correct his English translations. He wrote to Edward Thompson-already a competitor for Tagore's attentions-that if translations were not to be made by Tagore himself, 'the next best thing is to work with some Englishman who has literary abilities. I have every hope that Andrews will be willing to help me in this work when he comes back from England. . he knows very little Bengali but I know Bengali well enough to supply this deficiency'. ${ }^{39}$ But by the end of 1914, Andrews was ill in both body and mind and had severely tested Tagore's patience: his emotionalism was becoming something of a barrier and his literary abilities were in doubt. ${ }^{40}$ In short, Andrews-as a 'communicator' of Tagore to Western audiences-had significant limitations, not least because his deep sense of personal devotion compromised his relationship with the poet. Tagore craved independence and solitude as much as he may have craved recognition, and though their friendship was not in doubt as intellectuals, there existed an oceanic gulf between the two men.

So with time, Andrews focused less on translating and more on allowing Tagore to 'speak for himself'. Andrews had high hopes for the message that Tagore could send. This tendency had been evident back in 1912 when he tried

\footnotetext{
${ }^{36}$ C.F. Andrews, 'An Evening with Rabindra', in The Modern Review, Vol.11, no.2 (1912), p.228.

${ }^{37}$ W.B. Yeats to Edmund Gosse, 25 Nov. 1912, W.B. Yeats correspondence files, Tagore Papers, Rabindra Bhavana. Cf. Wade (ed.) The Letters of W.B. Yeats, pp.572-3.

${ }^{38}$ W.B. Yeats to Tagore, 9 Jan. 1913, published in Visva-Bharati Quarterly, Vol.30, no.3 (2003), p.163.

39 Tagore to Edward Thompson, 18 Feb. 1914, Ms. Eng. c.5318, folio 30, Thompson Papers, Bodleian. Cf. E.P. Thompson, Alien Homage: Edward Thompson and Rabindranath Tagore (Delhi: Oxford University Press, 1993), p.17.

${ }^{40}$ Cf. Dutta and Robinson, Rabindranath Tagore: An Anthology, p.155.
} 
to scotch plans for a Yeats-authored introduction to Tagore's work. 'I have written to Mr. Rothenstein about the introduction', Andrews told Tagore, and 'I wish [it] were more worthy of the poems. I read it over again yesterday in the train and it was altogether unsatisfying and very superficial. ... I wonder if in the popular edition they could stand by themselves without any introduction at all. That is what I should wish' ${ }^{41}$ Andrews' belief was no doubt naive, but it was honestly held: Tagore's 'giving....[of his] heart in its simplicity to [his] fellow men in the West... [would begin]', so Andrews wrote in 1914, 'to break down barriers'. ${ }^{42}$

The primary publications arising out of this approach were edited collections of Tagore's letters, such as the 1924 Letters from Abroad and the 1928 Letters to a Friend. These, as well as Thoughts from Tagore, published in 1929, gave further credence to the unfortunate and already obstructive idea of Tagore as the Eastern 'poet-seer'. Both books were published with the full consent of Rabindranath himself, but they may well have done more harm than good, presenting his ideas in aphoristic, de-contextualised form. Andrews often edited the letters, removing some of their more controversial aspects, in so doing reducing the complexity of Tagore's character. But we can still say that his intention was to rebalance the colonial relationship by facilitating the positive influence of the East on the West. In other words, by the 1920s, atonement-a common term used in thinking about how Indian-British relations might be improved-had become something more than just a gesture of recognition.

In addition to this form of promoting Tagore, a second move made by Andrews was to intensely personalise his idea of atonement as self-reform and reconfiguration. From 1914 onwards Andrews based himself at Tagore's ashram in Shantiniketan to pursue his spiritual development. In 1919 he renounced his Anglican ministry, and in later years exchanged his linen suits and clean-shaven appearance for a long, flowing Tagore-style robe and full beard. Abandoning his affiliation with colonial power also meant a change in personal habits and appearance. Above all, however, his atonement was acted out through devotion to Tagore.

There is a letter-undated but probably written long after the heady summer of 1912-to be found in the Tagore Papers at the Rabindra Bhavana archive in Shantiniketan. The letter says a great deal about Andrews' character and the power of his sense of desire. In the letter, he evokes the strength of his own

\footnotetext{
${ }^{41}$ C.F. Andrews to Tagore, 6 Oct. 1912, Correspondence Files (English), Tagore Papers, Rabindra Bhavana.

${ }^{42}$ Andrews to Tagore, 14 Jan. 1914, Andrews Files, Tagore Papers, Rabindra Bhavana.
} 
feelings as he recalls the night he first met Tagore. 'It was your English poems that I fell in love with', Andrews writes, 'they flooded my whole mind and soul and body'.

You were so shy: you shrank out of sight-'anywhere-anywhere, out of the world'-so that when the evening was over I had still only a very imperfect idea of your face and could not recall it. I had this one impression-a shrinking figure, frail and worn and very pitiful-and I did pity you, and all the mother in me went out to you in a yearning kind of way. Once or twice I went timidly up to you, but felt that I had failed.... When the evening was over I had almost forgotten you in the wonder of your poems. I had no room for anything else. I was literally intoxicated. I hardly knew what was happening to me, or what was going on around me.... I went out onto Hampstead Heath alone. It was a clear, soft moonlit night. I had the latch-key with me of the house where I was staying, and I remained out under the sky long into the night, almost till dawn was breaking. ${ }^{43}$

As the letter continues it develops an increasingly suggestive sense of interiority as it becomes fully confessional.

And then, when I did see you at last a second time, alone in your own house, this joy of expectation was more than fulfilled. For then I fully knew, as I had not fully known at that first meetingwhy should I not say it quite simply?-how beautiful you were.... Since that day when I first saw your face and looked into your eyes, it has ever been thus with me, and a hundred thousand times over I have repeated it to myself. It is not your beauty alone, but the vision of beauty that has come to me through you. ${ }^{44}$

If one of the tasks of historians is to empathise with historicised subjectivityto try as far as possible to think with people of the past-then manifestations of love seem to present significant challenges of interpretation. The assumptions of our time, it seems to me, are so engrained that they are difficult to 'un-think'. It is tempting, still, to read into this letter-and indeed numerous other letters - that Andrews was essentially 'in love' with Rabindranath. If this is true

${ }^{43}$ Andrews to Tagore, undated (and possibly unsent), Correspondence Files (typed copies), Andrews Papers, Rabindra Bhavana.

${ }^{44}$ Ibid. 
there is no evidence that it was reciprocated. There are letters between the two in which Andrews raises the subject of marriage, and in a 1915 letter from Willie Pearson-their mutual friend and Shantiniketan colleague-to Tagore, Pearson mentions the name of a 'Miss Dutt', an Indian Christian whom Andrews had considered marrying. ${ }^{45}$ But he never did marry. The theosophist James Henry Cousins, who met Andrews in India, wrote in his autobiography that Andrews had 'confided in me that what he had always wanted was a wife'. 'I had a private idea', Cousins adds, 'that what he needed was a husband, for he appeared to be a big hearted woman who had got mixed in his incarnation'. ${ }^{46}$

What is rather more important is that for Andrews, Tagore represented an alternative vision of the sublime, a Christ-like object of veneration, whobecause Tagore could be fused in Andrews' mind with India itself-offered the possibility of atonement through the inversion of the received racial, cultural and religious hierarchies established by colonial power. In politics, within a context of hardening divisions, Andrews identified himself very strongly with India over Britain, and by 1916 he effectively decided that 'a free India could have no place in the British Empire'. ${ }^{47}$ As E.P. Thompson claimed, sardonically, only those who, 'like Charlie Andrews. . .adopted without reserve the Indian point of view' could be trusted. ${ }^{48}$

Andrews' identification with subalternity extended into the realm of gender relations. Andrews had a deep reverence for the feminine, which, as I alluded to earlier, may have stemmed from the tremendous love he felt for his mother, and his worship of femininity-including femininity in men-involved a certain re-ordering of values. Andrews held radical ideas on women's rights, calling for the ordination of women into the Anglican clergy in 1940. In a pamphlet entitled 'The Good Shepherd', he wrote that 'just as in Christ there is neither Jew nor Greek', so also in Him there is 'neither male nor female...no subordination of one sex to the other' ${ }^{49}$ So his refusal of the binary of self and other extended to gender relations, and was acted out at the deepest levels of Andrews' personal life.

\footnotetext{
${ }^{45}$ William Pearson to Tagore, 5 Oct. 1915, Correspondence Files (English), Tagore Papers, Rabindra Bhavana.

${ }^{46}$ Quoted in Leela Gandhi, Postcolonial Theory (New York: Columbia University Press, 1998), pp.194-5, note 22.

${ }^{47}$ Tinker, The Ordeal of Love.

${ }^{48}$ Thompson, Alien Homage, p.104.

${ }^{49}$ Quoted in Gandhi, Postcolonial Theory, p.18.
} 
A final way for Andrews to act out his own personal atonement was to engage with the spiritual basis of Hinduism and Buddhism. Most revealingly, he drew heavily upon Tagore's knowledge of religion and philosophy to pursue an ongoing project on the Eastern and Western leanings of Christianity, which culminated in the 1932 publication What I Owe to Christ. In the numerous exchanges between Tagore and Andrews on the nature of Christianity, Andrews wrote of 'a more organic conception of the higher religions' based on a 'moving thought, which has come to me almost in the light of a new discovery... to find out from my own actual experience how much the old ethical and spiritual ideal of India itself (the Hindu-Buddhist ideal) is the distinctive note in Christ's own life, which marks him off from the Old Testament and from St. Paul'. ${ }^{50}$ He asked Tagore:

Would you agree with me that St. John is far more congenial to your Hindu mind than St. Paul? The Sermon on the Mount ideal repels us. ... An Indian student once said [to me]-'Sir, if I told an Englishman that he would "inherit the earth" he would be flattered and pleased: but if I told him he should be "meek" he would be insulted!'.... We have this old, hard, aggressive Jewish and Roman view of life running in our very blood. ${ }^{51}$

Andrews' project was to 'Easternise' the West via a re-examination of the history of Christianity, drawing out the supposedly forgotten 'Eastern Christ'. It was, perhaps, less syncretic and more oriented towards the recovery of a lost essence; less concerned with combining elements than reconfiguring on the basis of fresh experience and an alternative Eastern paradigm. Leaving aside the very obvious essentialisation of East and West implicit in Andrews' perspective, we can nevertheless see that he had a constant yearning for a move beyond atonement as gesture towards a transformative encounter, which involved a deep struggle to come to terms with his faith, and to reconcile the hopes and dreams that he had brought out to India in 1904 with the despoiled realities of a putative Christian Empire.

On the surface of things then, Andrews appears to be quite a radical figure. What I would like to suggest-and I shall return to this at the end-is that there are some core elements of British liberalism, a kind of British-ness if you will, that can be found in Andrews, most notably his gradualism, his belief in the role of elite individuals as agents of change, and his clinging on to a form of

\footnotetext{
${ }^{50}$ Andrews to Tagore, 2 Mar. 1914, Andrews Files, Tagore Papers, Rabindra Bhavana.

${ }^{51}$ Ibid.
} 
Fulfilment Theology in which Christianity plays the ultimate mediating role between East and West.

\section{E.J. Thompson: Justice as Critical Engagement}

Thompson's encounter with Tagore was, like Andrews', simultaneously deeply personal-effected on an individual basis-and macroscopic in its ambition to bring India and Britain towards reconciliation. But while Thompson was a man with a similar background to Andrews, he differed markedly in terms of temperament and intellectual disposition.

Thompson's father and mother were Wesleyan missionaries in South India, and although he was born near Manchester, it is said that Edward's earliest memories were of 'mission compounds and Madras beaches'. ${ }^{52}$ Thompson was ordained in 1910, and in the same year was sent to teach English at the Wesleyan Mission High School and College at Bankura, a small provincial town in what is now West Bengal, and he taught there until 1922, save for the period 1916 to 1919 when he was a chaplain with the British Army in Mesopotamia.

He had first met Tagore in Calcutta in October 1913, shortly before Tagore was awarded the Nobel Prize, and from the very beginning their relationship was a struggle. Thompson had written to his mother on 30 October that he had 'waded many rivers, cycled over 30 miles' to reach Tagore in Shantiniketan, only to eventually arrive at midnight and find that Rabindranath had gone to Calcutta. ${ }^{53}$ Thompson's next visit coincided with the arrival, on 14 November, of a telegram notifying Tagore of his Nobel Prize, and this time Tagore was at home. Preserved in Thompson's notebook is an account of this day, and it is suggestive of Thompson's attitude, for he was keen from the outset to move beyond the facade of hero worship and delve deeper into the complexities of Tagore's life and work. According to Thompson, the Shantiniketan schoolboys 'went mad', for although 'they didn't know what the Nobel prize was', they nonetheless 'understood that the gurudeb they adored had done something wonderful'. They 'formed ranks and marched around the ashram singing their school song'. ${ }^{54}$ But amidst all these celebrations in which, according to Thompson, 'a frenzy of worship seized

\footnotetext{
${ }^{52}$ Mary Lago, 'Edward John Thompson', Oxford Dictionary of National Biography [http:// www.oxforddnb.com/view/article/36487?docPos'/33, accessed 18 July 2011].

${ }^{53}$ Edward Thompson to Elizabeth Thompson, 30 Oct. 1913, Ms. Eng. d.2670, folio 33, Thompson Papers, Bodleian. Cf. Thompson, Alien Homage, p.1.

${ }^{54}$ Uma Das Gupta, 'Appendix: Tagore Learns of the Nobel Prize', in Thompson, Alien Homage, p.114.
} 
them and they, one after the other, threw themselves down and touched his feet... all masters, boys, servants', Thompson states that he remained 'an Englishman', who held 'stern contempt for the fools who pretend they are Easterners'. ${ }^{55}$ Thompson did not propose to atone for Empire by adopting Indian customs, nor by proclaiming the superiority of the East. He was unable, politically, to move beyond the idea that India should achieve dominion status within the Empire, but desperately wanted to find some kind of meaning in the imperial project, and specifically the encounter between Britain and India, as opposed to simply consigning it to the dustbin of history.

What Thompson offered by way of atonement was something that-as he saw it-was within his grasp to offer: a fair hearing and sound criticism. The intellectual exchange between Thompson and Tagore began from 1914, when Tagore was still obsessed by the quality of his translations. As mentioned earlier, Tagore was at this point becoming aware of both the impatience of genuine poets such as Yeats and Pound, as well as the intellectual shortcomings of someone like Andrews. As a man who was living and teaching in Bengal-and learning its language-Thompson represented a middle way, and throughout 1914 Tagore had asked Thompson to improve the 'diction and rhythm ${ }^{\prime 56}$ of some of his translations. The issue of translation has become an important one, connected as it has been to the decline of Tagore's Western reputation, but as E.P. Thompson rightly points out, his father was in fact responsible for a relatively small amount of translation work. ${ }^{57}$ In fact, before Thompson headed to Mesopotamia in 1916, he had already fallen out of favour with Tagore. Thompson was jealous of Tagore's time and attention and saw Andrews' hand in his rejection. He wrote to a Bengali friend in 1921 that Andrews was 'beneath contempt in terms of judgment ( \& intellect generally)'. 'I can't understand', he continued, 'how R. ever got humbugged into his ecstatic exaltation of him'. Of himself, Thompson remarked that he had 'always refused to worship indiscriminately', but nervously asked, 'I wonder if R. will have anything to do with me when he returns? ${ }^{158}$

Excluded from the intimate Tagore circle and unable to make his contribution through translations, Thompson pursued a different tack, and embarked on a

\footnotetext{
${ }^{55}$ Ibid., pp.114-5.

${ }^{56}$ Ibid., p.109.

57 Thompson, Alien Homage, pp.19-20.

${ }^{58}$ Edward Thompson to P.C. Mahalanobis, undated (probably Jan. 1921), quoted in Thompson, Alien Homage, p.33.
} 
full scale critical biography of Tagore, aiming to represent what he saw as the complexity of Tagore's poetry, as well as his social philosophy, which had been largely neglected up to this point. Writing to his wife about his forthcoming Rabindranath Tagore: His Life and Work, published in 1921, Thompson suggested that 'Andrews fondly imagines that I am putting together a rapt gazing at the master's face. There will be a few shocks...I'm aiming at something bigger - areal contribution to the truth'. ${ }^{59}$ What animated Thompson's actions was his belief that, as he put it, 'the world must pay Indian civilization the only compliment worth having, that of criticism by the best standards that sifting time has given us'. The biography was intended, he wrote to his wife, 'to give the West a pukka view of Rabi at last \& give Bengal a criticism of its stuff by universal standards'. ${ }^{60}$ The assumption was that judgement by so-called 'universal standards' was what Tagore desired.

Despite the obvious limitations of such a perspective, Thompson had in fact tapped into the deep ambivalences running through Tagore's mind during this period. Tagore himself had embarked on his mission to the West as part of a project of cultural exchange and enlightenment, and yet he was constantly fearful-with a private, but deeply felt sense of superiority-that much of the subtlety of his poetry and his thought would be lost on Western audiences, and he wrote to Thompson in 1922 to say he now felt that 'translating a poem is doing it wrong ${ }^{\prime}{ }^{61}$ At the same time-despite accusations of vanity-Tagore was often impatient with the sycophants who surrounded him, even with his friends if they exhibited similar tendencies, as the quote from the Pearson letter indicates.

And yet when Thompson's effort at criticism and serious engagement with his work came, it was not well received. In a furious letter to William Rothenstein, Tagore called Thompson's second biography of 1926, Rabindranath Tagore: Poet and Dramatist, 'one of the most absurd books. . .I have ever read dealing with a poet's life and writings':

All through his pages he has never allowed his readers to guess that he has a very imperfect knowledge of Bengali language which necessarily prevents him from realising the atmosphere of our words and therefore the colour and music and life of them.... For those who know Bengali his presentation of the subject is often

\footnotetext{
${ }^{59}$ Edward Thompson to Theodesia Thompson, 20 Sept. 1920, Ms. Eng. c.5357, folio 146, Thompson Papers, Bodleian. Cf. Thompson, Alien Homage, p.34.

${ }^{60}$ Edward Thompson to Theodesia Thompson, 9 Nov. 1920, Thompson Papers, Bodleian Library, also quoted in Thompson, Alien Homage, p.39.

${ }^{61}$ Tagore to Edward Thompson, 16 April 1922, quoted in Thompson, Alien Homage, p.48.
} 
ludicrously disproportionate.... Then again, being a Christian Missionary, his training makes him incapable of understanding some of the ideas that run all through my writings. ${ }^{62}$

Faced with the criticism that he apparently sought, Tagore recoiled in horror at its inadequacy, and indeed invoked cultural, religious and class distinctions in order to explain both Thompson's failure and his own anger.

In his book Alien Homage-about Thompson senior's relationship with Tagore-E.P. Thompson attempts a partial defence of his father's position: 'if Thompson's over-formal and over-self-confident critical standards are to be faulted', he suggests, 'these are the same standards he sought to bring to his criticism of English poetry'. ${ }^{63}$ But the point was quite obviously that such critical standards were Western standards masquerading as universal ones. Thompson's first book was published just two years after the Amritsar Massacre of 1919, at a time when nationalism was very much on the rise and sensitivities were high. But Thompson senior had written that the suppression of proper criticism was not natural, for 'we are not guests in their country', although he did add, 'as we shall be some day'. ${ }^{64}$ Still, in the mid 1920s, he assumed a right to criticise.

Back in England, Thompson did recognise the faults of his first book. In 1924 he wrote to a friend, 'I understand why my Tagore annoyed them, and I marvel that they bore with me in my Indian days. We are a gauche, crass lot ${ }^{\prime} .{ }^{65}$ But essentially he was undeterred. In fact, now low in Tagore's esteem, he pressed ahead with his efforts to realise the idea of atonement in a wider sense. Writing not of Amritsar but of the legacy of the 1857 uprising, he continued: 'I'm afraid I feel too bitterly about it. I'd like as an individual Englishman, to do my bit.... [1857 has] obsessed me of recent months.... I hitherto have been [a] very distinct moderate. .. but now I'm becoming a left-winger pretty fast'. ${ }^{66}$ Thompson had a healthy predilection towards self-mockery, but he was not, in any sense, becoming a 'left-winger'. Nevertheless the result of this obsession was his 1925 The Other Side of the Medal, a critique of the established historiography of the Indian Mutiny and an attempt to correct the balance sheet. In the book, Thompson pointed to the way in which memories of the Mutiny had created a number of myths that the British were now living by.

\footnotetext{
${ }^{62}$ Tagore to William Rothenstein, quoted in Thompson, Alien Homage, pp.40-41, emphasis in original.

${ }^{63}$ Thompson, Alien Homage, p.41

64 E.J. Thompson, Rabindranath Tagore: Poet and Dramatist, p.278, quoted in Thompson, Alien Homage, p.104.

${ }^{65}$ E.J. Thompson to E.W. Thompson, 26 June 1924, quoted in Parry, Delusions and Discoveries, p.163.

66 Ibid.
} 
He took issue with how 'our histories and our novels have proceeded on certain clearly marked lines'. In his account of these caricatures, Thompson suggested that

[t]here is the Indian, 'half-devil and half child', docile, patient, capable of a dog-like devotion, given to. . .mysticism and brooding contemplation, and yet with all these good qualities liable to perversion into a treacherous seditionist or blood-thirsty fanatic. .. [then] there is the Englishman, silent, efficient, inflexible, just, dispensing to each his deserts. It is not strange that Indians should be restive under such a portrayal' ${ }^{67}$

The Other Side of the Medal was intended to calm a troubled political relationship. Thompson was explicit and fervent that 'it is not larger measures of self-government for which they [Indians] are longing, it is the magnanimous gesture of a great nation, so great that it can afford to admit mistakes and wrong-doing, and is too proud to distort the facts' ${ }^{68}$ 'There is no commoner word on Indian lips today than atonement', he confidently declares, in the absence of any evidence. 'England, they say, has never made atonement; and she must do it before we can be friends. The word in their minds is the Sanskrit prayaschitta usually translated as atonement, but it means rather a gesture'. ${ }^{69}$ Thompson had just mocked the caricature of the Englishman, dispensing justice, and yet did not seem to appreciate the irony of his own position.

However incorrect or inappropriate his perspective was, Thompson believed it to be true and he acted accordingly. In 1924 he had written and published a play called, simply, Atonement, which was a precursor to his book on the Mutiny and explored themes of forgiveness and grievance. But in it the Indian characters, whilst protesting the injustices of the British, also accept a British right to rule and prerogative to act. Atonement for Thompson was a healing act that would stabilise the status quo without transformation of the political and ideological structures that had brought its instability into being. Well into the 1930s Thompson continued to publish on Indian history, co-authoring, with G.T. Garratt, Rise and Fulfillment of British Rule in India, a publication which was intended for an American audience and adopted a defensive tone,

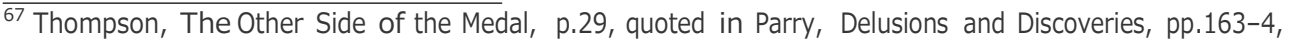
emphasis added.

${ }^{68}$ Ibid., p.164.

${ }^{69}$ Ibid.
} 
suggesting the apparent good that the British Empire had brought to India, whilst simultaneously trying to be fair-minded about its downsides.

Despite all the criticisms and rejections, Thompson was deeply loyal to Tagore until his death, often castigating him in private but steadfastly supporting him in public. He slowly began to rebuild his relationship with Tagore, who himself had perhaps mellowed a little by the 1930s. Like Andrews-and indeed like Tagore himself-Thompson placed a very high price on friendship. Indeed it has been suggested by E.P. Thompson that Thompson senior's prejudices and partialities should not simply be read within an 'imperialist' framework. 'In his own self-understanding', E.P. argued, 'it was rather that historical contingencies had brought about cultural, personal and intellectual associations between two nations, which should not be lightly thrown away'. The question was, 'after all this anger and ambition, what would remain ${ }^{\prime 70}$

The Limits of Tagore's Liberalism

Tagore's social philosophy certainly was not liberal, but he was engaged in a form of praxis that was decidedly so, centred on the function and value of the individual. In doing so Tagore exuded the elitism and fear of a demotic culture that is but one of the many paradoxes embedded in modern liberalism, and in fact joins together a very wide spectrum of political persuasions. In this sense, as Raymond Williams suggests, the pluralisation of individuals

is today the central definition of bourgeois ideology.... It commands the public ideals of a very wide range of orthodox political opinion, from modern conservatives through liberals to the most representative social democrats. It is a philosophy of the sovereignty of the civilized individual. . .against all those other and actual social forces which, in conflicts of interest. . .can be quickly assigned to the far side of... [the] border which is marked by its own definition of 'civilized'. ${ }^{71}$

Williams' position seems to me to be extremely germane to an understanding of the limitations of Tagore's liberal politics of friendship. Despite the ostensiblyprogressive credentials and intentions of all parties, the politics of friendship in the sense of this 'pluralisation' can and often did involve the rejection of a deeper transformative politics that might overturn the structural drivers of

\footnotetext{
70 Thompson, Alien Homage, p.104.

${ }^{71}$ Williams, Culture and Materialism, p.165.
} 
economy, class, gender and race that had given rise to the imperial situation. This limitation partly lay behind Tagore's conflict with Gandhi, which has been over-stated but remained deep in certain ways, and certainly underwrote the critique of Tagore by socialist writers and thinkers in the 1930s and onwards. Tagore and Gandhi-as Tapan Raychaudhuri has argued-were in fact much closer in terms of their vision of the good life and the importance they placed upon the social and religious underpinnings of Indian civilisation. ${ }^{72}$ But, although Tagore had sound philosophical grounds for his critique of what he saw as the negative and destructive aspects of Gandhi's swaraj, one cannot help but notice Tagore's recurrent fear of the irrationality of mass politics, as evidenced for him by the post-1905 Swadeshi Movement in Bengal. In other words, Tagore was happy to valorise Indian village life in some contexts, but unlike Gandhi he was not willing to ride the tiger of mass political mobilisation. As I have suggested, this was not unique to Tagore, but remains one of the many contradictions of modern liberalism.

I have already made some suggestions regarding the failure that was Yeats' encounter with Tagore, largely on account of the former's limited understanding of Tagore, but also due to Yeats' almost limitless belief in his own role as cultural critic and adjudicator of poetic and cultural value in a modern European context. But how to evaluate the two other encounters, between Tagore and Andrews, and between Tagore and Thompson? Andrews and Thompson-though certainly less interesting and complex in intellectual terms than Yeats-nonetheless provide an insight into the paradoxes of liberalism in the late colonial period.

To begin with, we should distinguish between the two forms of atonement that Thompson and Andrews enacted. The Christian idea of atonement has a range of meanings, from the idea of a quick absolution from sin through ritual or gesture to a much deeper and more transformative catharsis, perhaps ultimately represented by the death of Christ. Whilst Thompson longed for British-Indian relations to be healed, it was essentially with the intention of saving the Empire. In 1930 he had called the idea of Indian independence 'absurd and immoral' and he never fully reconciled himself with the idea of a complete severance. ${ }^{73}$ He would offer what he saw as the honourable gift of tough but fair-minded criticism and frank recognition of past wrongs. This was atonement of the

\footnotetext{
72 Tapan Raychaudhuri, 'Gandhi and Tagore: Where the Twain Meet', in Tapan Raychaudhuri, Perceptions, Emotions, Sensibilities: Essays on India's Colonial and Post-Colonial Experiences (Delhi: Oxford University Press, 2005), pp.141-51.

73 Parry, Delusions and Discoveries, p.154.
} 
gestural kind, though it would be fiercely unfair to describe it as tokenistic. Thompson's relationship with Tagore placed him in a compromised position, and in the partisan inter-war period a book such as The Other Side of the Medal represented a bold move. But he did not aim at a reconfiguration of political power relations. Nor did Thompson possess the personal qualities that would allow for a reinvention and transgression of any 'self-other' colonial divide. Andrews was a more fluid character, rejecting fixed, ascribed differences given by religion, culture and the political and social norms he inherited. He pushed across the boundaries of both personal and political difference.

Thompson may well have sympathised with Indian grievances, but he was all too often trapped within a colonial paradigm. As has been argued, he represented 'the paradox of moral conscience joined with ineradicable paternalist postures'. ${ }^{74}$ Moreover, whereas Andrews was apparently able to surrender his affiliation and give himself over to India wholeheartedly, Thompson's attraction to India was highly selective and elitist. It was easy to admire an intellectual of such standing as Rabindranath Tagore, but Thompson often exhibited repulsion and disgust at aspects of everyday Indian life and his insistence on a right to criticise was in fact indicative of a deeper anxiety which allowed space for highly-divergent attitudes towards Indians of different rank. Evidence of this can be found in the fact that Thompson was not averse to physical violence when it came to the lower orders. I quoted earlier from a 1912 letter Thompson had sent to his mother describing his arduous journey to Shantiniketan in search of Tagore. The letter is printed in E.P. Thompson's book about his father, but it is truncated. The E.P. version ends with Thompson senior, having 'waded many rivers', arriving at 2am to find that Tagore was in Calcutta. The original version-which can be found in the Bodleian Library, Oxford-continues thus: 'the chap in charge seemed to be dead-drunk and I was soon raving. There was no oil, no drinking water. The fellow moaned in Hindustani and we had quite a long interview; in the course of it I smacked his head twice'. ${ }^{75}$

One can only speculate whether, at a personal level, Thompson's own insecurities led to this kind of behaviour. E.M. Forster had mentioned Thompson in a list of 'Public Bores' drawn up in 1927. And with regard to the Thompson-Andrews-Tagore triangle, E.P. Thompson notes, with some degree of disdain, that C.F. Andrews had an 'imperial and missionary background

\footnotetext{
${ }^{74}$ Ibid., p.155.

75 Edward Thompson to Elizabeth Thompson, 30 Oct. 1913, Ms. Eng. d.2670, folio 33, Thompson Papers, Bodleian. Cf. Thompson, Alien Homage, p.1.
} 
more pukka than Edward Thompson's', ${ }^{\prime 6}$ whereas, he says, a Wesleyan missionary, at the 'back of beyond in. . Bankura, was something non-descript, perhaps low caste'. ${ }^{77}$ In support of this position E.P. Thompson cites a letter written in condescending tone by Tagore to William Rothenstein: 'he [Thompson] has been a schoolmaster in an Indian school and that comes out in his pages too often in his pompous spirit of self-confidence even in a realm where he ought to have been conscious of his limitations' ${ }^{78}$ As E.P. Thompson argued,

Tagore wrote in the confidence that elite was confiding to elite, subtly assimilating the English contempt of the 'babu' with upperclass scorn. The Methodists, like the Baptists, were rank outsiders to the Establishment, at a time when even the seditious C.F. Andrews could, with his pukka Anglican and educational credentials, still have an audience with Lord and Lady Hardinge. ${ }^{79}$

These divisions around class thus hold a double meaning. The conversation of elite to elite-the aspiration to pluralise the civilised individual through a politics of friendship-underwrote the possibilities of culture contact between Indian and Englishman, Tagore and his interlocutors. Despite often strongly diverging political views, these trans-national and trans-imperial elites united around an unspoken belief in their own inherent value and their capacity to speak to each other, and implicitly to speak for entire cultures or civilisations. At the same time class was a primary point of conflict and condescension within metropolitan British circles-that is between Europeans-but also, ultimately from Tagore to some of the 'lower class' Europeans who took it upon themselves to communicate Tagore to the West: for example the schoolmaster and the missionary. Where conflicts of interest arose, as the earlier Raymond Williams quote intimated, the class barrier could easily be re-invoked in order to mark the distinctions between comprehending and uncomprehending, qualified and unqualified.

Contrary to its utopian pretensions then, the politics of friendship can also be seen manifesting itself as a reactionary phenomenon, another example of a last

\footnotetext{
${ }^{76}$ Thompson, Alien Homage, p.3.

77 Ibid., p.9.

78 Tagore to William Rothenstein, 20 April 1927, quoted in Mary Lago, Imperfect Encounter: Letters of William Rothenstein and Rabindranath Tagore, 1911-1941 (Cambridge: Harvard University Press, 1972), p.321. Cf. Thompson, Alien Homage, p.9. In fact, Tagore's letter is far more cutting that Thompson's son, understandably, wishes to make clear.

${ }^{79}$ Thompson, Alien Homage, p.9.
} 
gasp attempt by the old elites-the dying intellectual priesthoods of a premodern, pre-national age-to shore up their common bond against the rising muddy tides of a demotic nationalism. As David Cannadine argued in his book Ornamentalism, class was a binding force in the imperial structure of feeling. Yet at the same time we see much evidence of ambivalence and tension between the status of the intellectual as a cross-cultural agent and the intellectual as a representative-and indeed sometimes the defender-of the national-cultural position. The cross-cultural relations of elite to elite were still, as has been shown, frequently mired in the insistent discord of cultural misunderstanding, defensive barriers and indeed occasional naked chauvinism.

Where does this leave Andrews, the so-called 'saintly Englishman'? Does his relationship with Tagore constitute, as the post-colonial theorist Leela Gandhi has suggested, a vision of an 'ethico-political practice of a desiring self inexorably drawn toward difference' which, 'manifested in the utopian politics of friendship, offers scope for greater inventiveness. . . manifesting a desire not only for dissolution but for the inauguration of new and better forms of community' ${ }^{80}$ Well, Andrews' transgression could be interpreted in a different way. It could be seen not as 'trans-national' or 'trans-cultural', in the sense of something shared across boundaries, but as requiring a complete crossing over; not as a movement above or beyond the national, but as a move in effect reinforcing the very same. In this sense Andrews' encounter with Tagore involved personal transformation, but also required the rejection of one form of collective identity as part of the acceptance of a new, other form. If this is so, then the process of transformation re-inscribes the colonial divide. In fact, both the 'crossing over' required by Andrews and the melancholic sense of loss experienced by Thompson were the consequences of a growing divide between coloniser and colonised, a divide that was arguably less politicised in an earlier, pre-nationalist and more liminal imperial age.

And yet there is a further level at which we might think about Andrews' apparent transgression of the colonial boundary, for this interpretation surely has to be complicated by the enduring presence of Christianity as a mediating force. The liberal yearnings of Fulfilment Theology, in which, rather than denunciation of the 'heathen', Christian writers and missionaries sought intimations of Christ in the religion of the Hindu, are evident in the work of both Thompson and Andrews, but were taken much further by the latter's

\footnotetext{
${ }^{80}$ Leela Gandhi, Affective Communities: Anticolonial Thought, Fin-De-Siecle Radicalism, and the Politics of Friendship (Durham: Duke University Press, 2006), p.6.
} 
search for the 'Eastern Christ'. ${ }^{81}$ Fulfilment Theology, which had struck such a distinctive note in the metropolitan reception of Rammohun, Keshub, Vivekenanda, Tagore and others allowed Christianity to retain its central place in the forward movement of World History, and even in a watered-down version, at this very late imperial denouement (a stage at which the liberal project of Empire had evidently failed) it can be seen as a last refuge for those who were unable or unwilling to move beyond the potentialities of an earlier, more optimistic historical moment.

If we are seeking lessons for the present, dangerous though such an approach can be, what emerges from the historical accounts of the relationship between Tagore and many of his Western interlocutors is a strong degree of uncertainty regarding the emancipatory claims of a trans-national 'politics of friendship'. As individuals, Thompson's and Andrews' life histories offer insights into the conflicted personal narratives of inter-war liberalism, and the ambivalences of 'end of Empire' cultural and intellectual networks. But whether-even in the gentle, loving and all-embracing form of C.F. Andrews-they offer visions of a new kind of post-colonial politics remains an open question. Andrews and Thompson were both practising the politics of friendship but were equally trapped, in different ways, within certain paradigms of British imperialism: justice as impartiality for Thompson, and the Fulfilment Theology of a progressive Christianity for Andrews.

For all four men discussed in this article-Yeats, Andrews, Thompson and Tagore-the liberalism embedded in the politics of friendship was a surface manifestation of a deep structure not necessarily dividing East and West and not confined solely to Williams' bourgeois moment, but part of a more universal 'Brahminical' (loosely defined) culture. And yet the elites of the republic of letters-who saw themselves as inhabiting an autonomous social space separate from the corrupt and manipulative forces of imperialism and nationalism, and yet floating above the vulgarities of mass democratic politics-were caught in a historical trap. Despite the idealism, despite the high-minded desire, their associations were often beset by the very conflicts of class, race, religion and nation that they were supposed to transcend. Even in these most 'cosmopolitan' of milieux, the universal and particular, the home and the world, remained very much in tension.

\footnotetext{
${ }^{81}$ Hayden J.A. Bellenoit, Missionary Education and Empire in Late Colonial India, 1860-1920 (London: Pickering \& Chatto, 2007).
} 